\title{
Atividades Interativas como Forma de Contribuir para a Humanização no Setor Pediátrico: Relato de Experiência
}

\author{
Moreira, Stephanie Louzada; Lima, Marina Dayrell de Oliveira; Barata, Jaqueline \\ Marques Lara
}

Pontifícia Universidade Católica de Minas Gerais — stephaniemoreira@outlook.com

Introdução: Humanizar na atenção à saúde é entender cada pessoa em sua singularidade, considerando suas necessidades específicas, criando condições para que tenha maiores possibilidades de exercer sua vontade de forma autônoma (FORTES, 2004). Diz respeito ao tratamento das pessoas levando em conta seus valores e vivências como únicos, evitando quaisquer formas de discriminação negativa, de perda da autonomia, preservando a dignidade do ser humano (RECH, 2003). a realização de atividades lúdicas e interativas com as crianças hospitalizadas, bem como as rodas de conversa com os profissionais buscam, em consonância com a Política Nacional de Humanização, tornar o ambiente hospitalar mais acolhedor por amenizar os sentimentos que a internação causa para as crianças e pela criação de espaços de diálogo, em que os trabalhadores possam se expressar, e sobretudo, trocarem experiências. em ambas as atividades, o objetivo é estimular a construção da autonomia dos sujeitos por meio da problematização, através da valorização dos saberes e dos atores envolvidos. Objetivo: Relatar as experiências vivenciadas no setor Pediátrico de um hospital público. Método: Estudo descritivo, do tipo relato de experiência, sobre as atividades do projeto "Atividades Interativas como forma de contribuir para a humanização no setor pediátrico" desenvolvido pelo setor de Humanização. Foram realizadas com as crianças diversas atividades lúdicas e interativas voltadas para a estimulação à criatividade, autonomia e diversão, além de algumas destas possuírem foco em educação em saúde. Quanto aos profissionais, foram realizadas rodas de conversa com temas considerados relevantes da prática em saúde, como comunicação, trabalho em equipe e outros. Resultados: o ambiente hospitalar é considerado fator estressor nos diversos tratamentos infantis e muitas vezes a criança se sente angustiada, ansiosa e com medo, além de impossibilitada de frequentar a escola e grupos infantis de convivência. Nesse sentido, ao implementar atividades durante o tempo em que ficaram internadas, percebemos que pequena parte de sua rotina antes da hospitalização é recuperada, o que muitas vezes contribui para uma resposta terapêutica mais eficaz. em relação às rodas de conversa com profissionais do setor, é possível notar que houve uma grande interação entre os mesmos ao discutir os temas que lhes foram propostos, o que permitiu não só a troca de experiências mas também contribuiu no trabalho em equipe e em uma assistência acolhedora. Conclusões: Foi possível, através da execução do projeto, sensibilizar os profissionais para a prestação de uma assistência mais humanizada, pautada na identificação de fatores estressantes para os mesmos, para as crianças e familiares que tenham na interação o ponto de partida para o reconhecimento do outro e, portanto, portador de demandas únicas.

Moreira, Stephanie Louzada; Lima, Marina Dayrell de Oliveira; Barata, Jaqueline Marques Lara. Atividades Interativas como Forma de Contribuir para a Humanização no Setor Pediátrico: Relato de Experiência. In: Anais do Congresso Internacional de Humanidades \& Humanização em Saúde [= Blucher Medical Proceedings, num.2, vol.1]. São Paulo: Editora Blucher, 2014. ISSN 2357-7282

DOI 10.5151/medpro-cihhs-10379 